\title{
Diffusion and the Constitutionalization of Europe
}

Comparative Political Studies 43(8/9) 969-999

(C) The Author(s) 2010

Reprints and permission: http://www. sagepub.com/journalsPermissions.nav DOI: |0.1 I77/00104|4010370433 http://cps.sagepub.com

@SAGE

\section{Zachary Elkins'}

\begin{abstract}
This article begins with a rather forceful defense of the explanatory role of formal institutions-and, in particular, constitutions-in the study of democratization. Important aspects of constitutions play a significant part in shaping the quality, type, and survival of institutional arrangements in new democracies. With this assumption, the article turns seriously to theories of constitutional design, any of which must grapple with the overwhelming prima facie evidence of constitutional diffusion. It is well known that constitutional ideas travel easily across contexts. However, scholars until now have lacked even basic empirical evidence regarding the patterns of constitutional similarity across time and space. This article introduces exactly this sort of evidence in the context of 19th-century Europe, employing a new data set expressly designed for such a purpose. The analysis uncovers a number of new insights regarding the spread of constitutional ideas in Europe, insights that disturb some of the classic narratives of democratization in these cases.
\end{abstract}

\section{Keywords}

democracy, democratization, diffusion, constitutional design, Europe

"History ... is far too important a topic to be just left to historians" (p. 347), noted Dankwart Rustow in his seminal 1970 article on the process of democratization. Rustow's article, in turn, helped to transform at least two generations

'University of Texas at Austin, Austin, TX, USA

\section{Corresponding Author:}

Zachary Elkins, University of Texas at Austin, Department of Government, I University Station, A 1800, Austin, TX 787 I2

Email: zelkins@austin.utexas.edu 
of political scientists into avid historians bent-almost relentlessly-on pursuing the sources of regime change. Now, researchers are returning to deeper reaches of history to reevaluate the seemingly settled ideas regarding the democratization in 19th-century Europe. The conventional wisdom regarding these cases stems in large part from a set of canonical works (notably Luebbert, 1991; Moore, 1966; Rueschemeyer, Stephens, \& Stephens, 1992) that point to the explanatory power of a variation in class arrangements. Nevertheless, the very idea of democratic waves implies another important set of causal factors: that the decisions of actors in one jurisdiction affect decisions in another, a set of processes that sometimes goes under the label of diffusion. A renewed focus on these more international factors - which have always been at least a background consideration for democratization scholars - is one of the hallmarks of recent research on the subject (Capoccia \& Ziblatt, 2010). Using various analytic tools, democratization scholars have struggled to diagnose these interdependent processes in second- and third-wave cases (e.g., R. B. Collier, 1993; Coppedge \& Brinks, 2006; Kopstein \& Reilly, 2000). The objective of this article is to explore the possibility of diffusion in cases of institutional reform in 19th-century Europe. My particular focus is on the patterns of change in written constitutions, the quintessential, if sometimes overly formal, manifestation of a country's democratic political institutions.

This analytic and substantive turn toward constitutions does not come without apparent costs, and there we begin. The view espoused herein is that the benefits of reading democratization through the lens of constitutional reform far outweigh any costs. Indeed, the analysis of the content of constitutions communicates an enormous amount of information about the process, nature, and probability of democratic reform. These benefits accrue despite the skepticism of some about the efficacy of constitutions in young democracies. In turn, if constitutional choices have consequences for democracy, then it follows that diffusion - which we strongly suspect, uncontroversially, of shaping constitutional design - is also part of the democratization story. On this point, the literature on the transfer of institutions in Europe lacks answers to some of the most basic empirical questions, a gap I endeavor to fill with a focus on early-19th-century developments. Which of the world's constitutions were most central to European drafters? Along which networks of influence did constitutional ideas flow? In a macro analysis of the elements of European constitutions, the analysis below demonstrates some less obvious but still undeniably consequential effects of diffusion in the European context. These effects are all the more apparent once we drill down to several episodes of constitution making, an approach advocated by Capoccia and Ziblatt (2010). Thus, in a process-oriented analysis, I examine the initial 
sequence of constitutional decisions in Spain and Portugal at the beginning of the 19th century. These constitutions, as it happens, represent extremely important decisions (for both Iberian and non-Iberian successors alike), and the role of diffusion in at least the Iberian cases seems to have had far-reaching effects on democracy.

More broadly, the analysis below has real implications for the scholarly agenda. Specifically, all told, the evidence suggests reasons to be sanguine about the return of democracy scholars to the "cold cases" from 19th-century Europe. Certainly, there is still much yet to be wrung from these important cases, and by no means should we consider them closed.

\section{Written Constitutions and Democratization}

That constitutions should have something to do with the development and performance of democracy is not at all obvious. Indeed, one could be excused for thinking the opposite. It is not unusual to read the following observation about higher law in new democracies, in this case contemporary Africa:

Although every African country has a constitution as well as a body of laws and administrative procedures that place formal limits on executive power, the long-held consensus among observers is that these rules play very little role in actually constraining leaders' behavior. (Posner \& Young, 2007, p. 127)

One could easily substitute "19th-century European" for "African" in Posner and Young's (2007) sentence without much dispute from historians. But, of course, it should be of no surprise to observe that constitutions matter in some places and at some times and not everywhere and not always. Indeed, a profitable research program would be one dedicated to understanding the conditional impact of constitutions better. But what, if anything, can the study of nonconstitutionalist constitutions tell us about democratic reform? ${ }^{1}$

One answer is that intentions matter. One wants to know why drafterswho often believe, if delusionally, that they are constructing the foundation of a democratic state - decide on one constitutional provision rather than another. This curiosity would persist even, perhaps especially, in cases in which constitutions do not constrain government (as in, why do such constitutions not "work"?). In this sense, constitutional drafters have deposited a very useful set of historical records of episodes of intentional institutional reform, whether or not the drafters' reform is ever realized. Indeed, that claim may even put things too mildly. Compared to the historical material that scholars usually consult to 
document the democratization "process" of democratic transitions, the decisions and deliberations of constitutional drafters provide a degree of precision, concreteness, and yes relevance that is unmatched.

\section{Exploring Some Assumptions About Constitutions and Democracy}

These claims may still strike those derisive of constitutions as empty rhetoric. It seems useful, therefore, to establish some empirical moorings before proceeding further. To begin, consider three empirical regularities concerning the history of constitutions and democracy, regularities that provide a better historical sense of the nexus of these two concepts.

First, constitutions may not always lead to democracy, but it is nearly unthinkable - or at least nearly unprecedented in the modern era - that a state would achieve democracy without a constitution. Except for Great Britain, no state since 1800 has achieved a score of full democracy (on any of the historical indices such as Polity) without adopting a written constitution. I introduce this coincidence not to state a necessary condition for democracy but rather to note simply that democratization and constitution writing have developed concurrently and are part of the normative script for the respectable modern state. One implication of this observation, then, is the reminder that written constitutions are indeed likely to serve as a useful record of at least the public and institutional designs of democrats. The record offers distinct analytic benefits. In contrast to the highly abstract, aggregate, and often wide-ranging historical material used to build stories of transition to democracy, constitutions make for a very tractable and discrete unit of analysis. To take only one case, consider Mexico, which progressed gradually toward democracy over a 70-year period but to which scholars typically pin a transition date of 2000 (or sometimes 1994; Alvarez, Cheibub, Limongi, \& Przeworski, 1996). Studying and documenting the decision process of the protracted Mexican transition as an event presents serious challenges for those who would insist we look beyond the 2000 and 1994 elections. By contrast, the almost yearly reforms to the 1917 constitution — and their accompanying debate — mark the evolutionary changes in democratic institutions in an illuminating and concrete way.

A second empirical regularity is that constitutions are nearly universal among states after 1800 but democracy is not, which is to say that ruling authoritarians are as likely to have a constitution in force (at least formally) as are ruling democrats. In small part, this lack of correspondence between constitutions and democracy is explained by a certain flexibility of the constitutional form. Even autocrats like to write down the organizational form of 
government (witness Singapore), even if they are not always inclined to include elections, rights, and independent commissions. However, these sorts of illiberal constitutions are exceedingly rare. The overwhelming majority of constitutions written by authoritarians formally espouse democratic principles and provide for democratic institutions. For example, of the historical constitutions written during authoritarian settings (defined by a Polity score of less than 6), 82\% include provisions for the right to free speech as opposed to $88 \%$ of constitutions written in democratic settings. We can say the same for other traditional civil rights such as right to assembly ( $76 \%$ vs. $89 \%$ ), freedom of the press ( $51 \%$ vs. $57 \%$ ), and even provisions to elect members of the legislature ( $25 \%$ vs. $34 \%$ ), which are uncommon in any constitution but not much more uncommon in "authoritarian" constitutions (Comparative Constitutions Project). These numbers do not suggest striking differences in content between authoritarian and democratic products. Therefore, most of the gap between the near universality of constitutional regimes and the more exclusive set of democratic regimes is explained by the phenomenon of authoritarians governing with a loosely or selectively enforced democratic constitution.

One can rattle off one's favorite cases of authoritarian regimes with resplendently democratic constitutions. Often, the poster children for this cause are regimes of the authoritarian Left, whether it be the Soviet Union or the various and nearly extinct republics with "People" in their name. In the constitutions of many of these states, modes of democratic participation are many and varied, all manner of rights are in evidence, and the citizens are championed as sovereign. Those of the authoritarian Right are equally likely, in their own way, to write democratic institutions into their constitutions, often with the same allegations of hypocrisy from critics. The adherence to democracy in formal constitutions speaks, perhaps, to the power of democracy as an international norm, or at least to universal aspirations among drafters for democracy at some point in the future. Either way, the point is that constitutions are almost exclusively democratic in form, regardless of their application.

The universality of the democratic form in constitutional design, if not practice, may actually explain, in part, a third empirical regularity: the surprisingly loose connection between regime change and constitutional change. It seems reasonable to expect that regime change and constitutional change would go hand in hand. Not so. Roughly $19 \%$ and $27 \%$ of transitions to democracy and authoritarianism, respectively, coincide with constitutional change (Elkins, Ginsburg, \& Melton, 2009). ${ }^{2}$ New authoritarians may be slightly more likely to write constitutions than are new democrats following a transition, but that represents a small difference: The broader point is that neither is automatically inclined to do so, at least immediately. One explanation for this disjuncture may lie in the interest of actors to preserve constitutional 
stability or accommodate elements of the ancien régime (e.g., Chile following the departure of Pinochet). Another may be, simply, that leaders within both regimes are accustomed to live with and write democratic constitutions and so they can as often as not share a constitutional document. In this sense, the democrat's response may be to step up enforcement of the document ("Finally!" he might say); the authoritarian's response may be to ignore at least parts of it (“Constitution? What constitution?"). In any case, the moderate connection between constitutional replacement and regime change suggests that (a) new constitutions will not always coincide with democratic milestones, and vice versa, and (b) students of democratization may need to pay attention to allegedly "authoritarian" constitutions as well as "democratic" ones since marking them as such may not make sense.

To be sure, we should be wary of placing too much stock in the parchment promises of authoritarians. Nevertheless, there are at least two more reasons why we should temper our derision toward even these constitutions. For one thing, as a number of scholars have shown, the presence of some democratic institutions - however enforced - in an authoritarian setting is significantly better (i.e., more democratic) than none (Lindberg, 2006; Przeworski, 2010). Second, as I noted above, constitutions are famously aspirational, and there is reason to believe that democratic seeds need time to take root. One does not have to look far to find cases of aspirational constitutions whose succeeding generations have fulfilled even its most fantastic promises. For example, it took at least a generation to realize the provisions of the Mexican constitution of 1917, one of the more progressive documents of this century. In retrospect, the parchment promises of 1917 have been formative. All this to say that even the seemingly hypocritical constitutions of the authoritarian can bear some democratic fruit later.

Together, these three empirical regularities amount to an important understanding about constitutions. Writing constitutions - in whatever setting-is largely a process of forming and designing democratic institutions, not authoritarian ones. Outcomes (i.e., de facto constitutional practice) may vary widely, but de jure constitutional design is decidedly democratic, and scholars of democracy should take note, to say the least.

\section{Theoretical Foundations of the Nexus of Constitutions and Democracy}

Why are constitutions intrinsic to democracy? The history of ideas suggests a simple answer. Constitutions are the written manifestation of the social contract, a concept central to the mind-set of democratic founders in the 19th century and beyond. As evidence of the wide applicability of the 
concept, consider that the prescriptions of contractarian theorists span various democratic forms, from the constitutional monarchy espoused by Hobbes to the liberal democracy promoted by Locke and Rousseau. It is hardly too literal to suggest that the logical expression of the exchange of citizen consent for limits on the sovereign is a written constitutional contract. One can argue, of course, that limited government (contractarianism) is not equivalent to democracy. For example, the sovereign can agree not to trample on the basic freedoms of conscience, association, expression, and property and still deprive citizens of representative, much less direct, government. At the minimum, however, assuming that a contract does not simply displace power, its imposition of limits on the sovereign (of population $N$ ) will nearly always have the effect of sharing power (if only a small amount) with a larger group numbering $N+1$, and thus shift regimes in a direction away from autocracy.

However, even if one agrees that constitutions are inherently democratizing, one might argue that the written contract remains, effectively, a philosophical abstraction because even in the presence of a physical text, citizens lack any mechanism of enforcement. Parchment barriers may remain just that, parchment. After all, who is to punish the sovereign when he or she sends the military to close a meeting of unionists? The unionists? The citizenry at large? The aged magistrates assigned to identify breaches to the social contract, assuming that they could even agree on such?

No. Constitutions may be written like contracts, but they operate more like coordinating mechanisms. This point accords with important contributions to the study of constitutional enforcement (e.g., Ordeshook, 1992; Przeworski, 1991; Weingast, 1997). Weingast's (1997) model is particularly instructive here. In his scenario, the only way to ensure that the sovereign abides by the social contract is for citizens to challenge his or her transgressions collectively. Partial challenges will be steamrolled by the sovereign, and therefore citizens will not challenge his or her transgression unless they expect support from their fellow citizens. Critical to expecting reinforcement is a unified understanding of, and respect for, the limits of the social contract. Only then can citizens coordinate to challenge the sovereign. Some constitutions lead to a unified understanding of, and respect for, their limits better than others. Elsewhere, I (with my coauthors) have suggested that clarity of interpretation is enhanced by specific (not framework) documents that provide for interpretation by a respected arbiter and that widespread attachment to the document is generated by participatory adoption processes and reinforced by constitutional longevity (Elkins et al., 2009). In complementary fashion, reasonably low-cost amendment rules and the presence of a mechanism for interpretive changes encourage the sovereign to avoid transgression by adapting the 
constitution, thus prolonging it and reinforcing clarity and attachment. These particular hypotheses may be disputed, but most of us would agree with the larger point: that some constitutions - based on their content and process of adoption - may be better than others in coordinating citizen challenges to sovereign transgression. Ideally, the result of this coordination is the equilibrium that we often celebrate as consolidated democracy. In that scenario, the sovereign expects united opposition to his or her transgression and declines to transgress in the first place. Thus, the important quality of self-enforcement.

The important implication of this line of reasoning is that the content of constitutions has profound effects on the stability and quality of democracy in a given polity. These consequences follow both from the varying ability of constitutions to coordinate citizens and constrain the sovereign (i.e., attributes like those I suggest above) and, perhaps more obviously, from the particular mix of institutional choices that framers make. This last point, I would guess, is less controversial than the first, even if there continues to be some dispute between institutionalists (e.g., Duverger, 1954) and those privileging social structure (e.g., Lipset \& Rokkan, 1967) — to take two classic stancesabout the relative weight of institutions and social cleavages in determining democratic outcomes. Surely, however, no one would deny that differences in the choice of executive-legislative arrangements (e.g., presidentialism vs. parliamentarism), electoral systems, and the provision of rights has no effect on the kind of democracy that citizens experience. Indeed, a poll of contemporary political scientists might suggest quite the opposite.

In summary, constitutions have unique analytic benefits for the student of democratic reform. They record, at the very least, the intentions of democratic reformers. Moreover, they serve a critical function in democracies: coordinating citizen defense of the limits on the sovereign. Importantly, some constitutions will foster coordination better than others, and undoubtedly, some constitutional provisions will alter the character and quality of democratic governance. To the degree that we can account for these differences in content, we can presumably say a great deal about paths of democracy.

\section{Diffusion, Critical Junctures, and Constitutional Design}

If one is at all inclined to grant a role for constitutions in shaping democratic institutions, then one must develop a theory of constitutional design. One view of such design may be that constitutions are purely epiphenomenal in that they are nothing but a reflection of domestic political forces and traditions - the "real" source of political change. In this view, constitutions 
merely enshrine the norms and customs already in place. If one were to push this line to the extreme, one might argue that the French document of 1791 merely enshrined the accepted rights and privileges of French citizens and clarified the rules by which Louis XVI would exercise authority. Of course, nobody - from the nobility to the church to the royals to the third estatewould view the document in such terms. Nor is the French charter of 1791-as revolutionary as it was - exceptional in this sense. Indeed, as I noted above, constitutional designers are more likely to fantasize about what political society could be than they are to record what it $i s$. In this sense, an assumption of epiphenomenal constitutions would not disturb in the slightest most "classic" accounts of European democratization (Capoccia \& Ziblatt, 2010). Whatever the effect on democracy of class structure, cultural predisposition, and the level of economic development, these variables would be baked into the constitutional design. In that view, the constitution would only reinforce a country's historical trajectory and predisposition toward democracy, not exercise any independent effect on it.

By contrast, an assumption of exogenous constitutional design profoundly disturbs these classic explanations. If a constitutional design transcends the basic contours of a particular political and historical environment, then we must look at the factors that predict that design. Without the space to construct a full theoretical model of constitutional design, it seems reasonable enough to assert that diffusion - by some mechanism or another-plays a large role.

Constitutions burst on the international scene at the turn of the 18th century. In 1786, no independent country had a legal document that it called its "constitution"; by 1875 all but a handful of countries had such a document. In some cases, this rapid change in the documentation of fundamental institutions was merely nominal. In the preconstitutional era, other documents such as the Magna Carta or the treaty-like Articles of Confederation of the United States had performed functions similar to modern constitutions. Even nominal changes can be consequential, however, and for many states the writing of a new constitution ushered in a marked shift in their institutional landscape. In a global sense, moreover, the widespread adoption of this new legal instrument set for the first time an international standard for how countries should proclaim their sovereignty and contract among their contending political, social, and economic groups. By mid-19th century, the founding charter was as much a part of the required script for independent states as was a flag, a national anthem, and a motto. This shift in legal convention has analytic implications. The timing of the emergence of modern constitution means that the texts that I analyze below are decidedly 18 th- and 19th-century products, 
not preserved documents from an earlier era. This point matters given that our intention is to understand shifts in 19th- and early-20th-century thinking.

Even a cursory understanding of constitutional history leads one to suspect that some degree of transfer of ideas, if not outright plagiarism, was at work in the drafting of these charters. As one might expect from the sudden and pervasive emergence of constitutions after 1787, the resulting texts bore striking similarities. Legend has it that some constitutions in the 1800s shared not only the same provisions but also the same typographical errors. How is it that the most fundamental governing laws of states - documents that often symbolize the independence and sovereignty of such countries - could be mere reproductions? Elsewhere I have theorized (Elkins, 2009) about the various inducements and constraints that lead constitution makers to entertain foreign models, but those specific mechanisms are largely unimportant to our mission here. Suffice it to say that a collection of drafters pressed to build the foundations of government in a short period of time and with multiple and conflicting imperatives does not shy from reviewing the examples of other countries. The idea of constitutional borrowing violently collides with the assumption of unit independence that Capoccia and Ziblatt (2010) rightfully question in the context of European democratization. If constitutions are, at least in part, imported, and if constitutions structure the performance and nature of democracy, then we will be ignoring an important - and interesting-factor explaining democratic reform by treating constitutional design experiences as independent.

But this acknowledgment of interdependence leads to another assumption that democratization scholars have begun to question: that of unit homogeneity. Just as the effects of domestic variables - whether they be structural, contingent, or cultural - are likely to have conditional effects, so too will factors such as diffusion. Neighborhood effects, for example, may not work the same way in one region as they would in another region. Europe, for reasons that I detail below, had a much more complicated set of constitutional influences than did Latin America (the other region undergoing rapid constitutionalization at the time), and thus we should see a more complicated regional pattern in Europe.

Any theory of constitutional design must also grapple with the fact that design is episodic. The asynchronic nature of constitutional development implies that we should think of constitutional - and, thus, democraticchange as one characterized by periods of stability interrupted by short sharp moments of change. In short, a process of punctuated equilibrium, to use the evolutionary catch phrase. Most of this has to do with the high costs of formal constitutional change. Certainly, incremental constitutional adjustment 
is possible by informal means-for example, as norms develop or leading actors vary the accepted interpretation of the text. However, formal change of entrenched higher law requires widespread consent, sufficient motivation, and a fair amount of societal coordination. Constitutions, after all, are intended to last with only a modicum of periodic formal adjustment. As such, constitutional commitments, by design, entail significant costs to undo. Witness the difficulty of assembling the various delegates to Philadelphia in the summer of 1787 and the resistance to their replacing (not amending) the Articles of Confederation. These assemblies of "demigods" (Jefferson) ${ }^{3}$ are not likely to happen often.

The historical implication is that constitutional (and democratic) development will be fitful, and the analytic implication is that one should study episodes rather than characterize periods. Capoccia and Ziblatt (2010) make this recommendation with respect to democratization more generally. In the case of constitutional history, their advice is particularly germane. Fortunately, constitutional design tends to be a fairly public endeavor, and their episodes should not be shrouded in mystery. Historians and the media alike are under the impression - corroborated, I hope, by my soundings here - that moments of constitutional design matter. With their documentation, we generally can reconstruct some semblance of the decision-making process, the basic contours of the debate during the deliberative moments, the various participants and their constituencies, how their product was received by the larger public, and of course how the document was treated and mistreated in subsequent years. What results is, comparatively speaking, a fairly illuminating picture of a critical moment in the development of political institutions (Capoccia \& Kelemen, 2007).

\section{The Constitutionalization of Europe}

\section{Analytic Design}

If this theory makes at least intuitive sense, then our empirical marching orders are fairly clear. For one, we must trace the DNA of constitutions. This means understanding the degree to which, if at all, constitutions owe an intellectual debt to prior domestic constitutions and prior foreign constitutions. We do not have a clear sense of these lineages or the mechanisms that sired them. At the most basic level, we have very little systematic knowledge of patterns of similarity among the various documents. It is quite common for scholars, in discussing particular constitutions, to point out the various influences on, and intellectual antecedents of, the documents. But how much influence? Are 


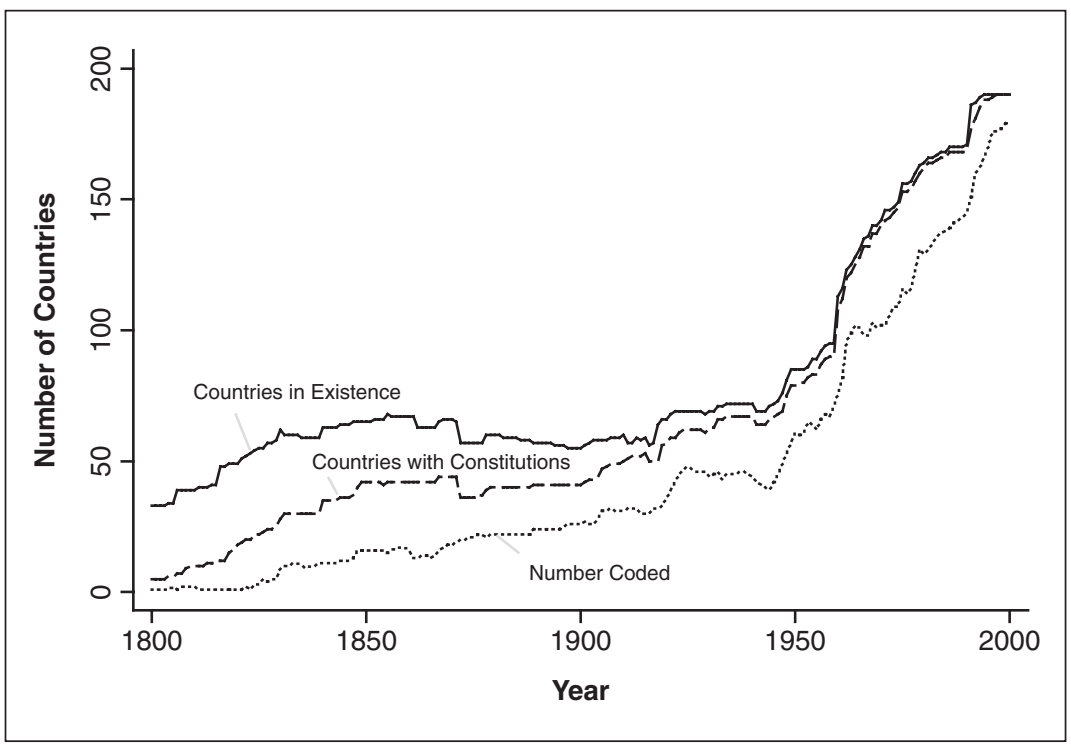

Figure I. Comparative Constitutions Project: Universe and sample (as of October 2008)

those influences manifest when one looks at the content systematically and compares the shared content across an entire set of constitutions?

In tracing the roots of national constitutions, I tap an original data resource expressly created for uncovering patterns of constitutional diffusion. That resource, the Comparative Constitutions Project (Elkins \& Ginsburg, 2010), records a large set of characteristics of constitutions for nearly every independent state since 1789 . The sample currently includes all constitutions in force since 1945 and roughly $60 \%$ of those suspended or replaced before then. Figure 1 more clearly describes both the sample and the universe of cases. More information on the sample, the measurement of central concepts, and coding procedures are available online at the project's Web site. ${ }^{4}$

A second analytic responsibility is to revisit - selectively - particular constitutional moments to understand more concretely, and in more illuminating fashion, the process that generated these contracts. Accordingly I focus on the first constitutions of Spain and Portugal, two cases that provide distinct analytic advantages. In many ways, these are countries that faced very similar constitutional problems. However, their constitutional assemblies were markedly different in terms of their setting and the identity of the participants. 
Nevertheless, the resulting Portuguese constitution followed the earlier Spanish document quite closely. These choices would prove to have lasting effects on the constitutional evolution of Spain and Portugal and, by association, the evolution of politics in countries inspired by the Iberian constitutions.

\section{The Rise of Contracting}

The constitutionalization of European states following the promulgation of the U.S. document in 1789 was rapid and thorough. In the space of 50 years following the Philadelphia convention, constitutions had become a thoroughly necessary trapping in the script of European statehood. Figure 1 provides a sense of the rapid adoption of written constitutions after 1789. In fact, only two states in Europe that existed prior to 1789 adopted constitutions later than 1850, and both of these (Monaco in 1911 and Andorra in 1993) are city-states and understandably atypical.

In some ways, the rapid constitutionalization of Europe is surprising. For states founded after 1789, the need for a constitution would seem obvious. Such states are under especially strong pressures to proclaim and legitimize their sovereignty. But for European states that had functioned well enough without a constitution for years, to follow fashion and write such a contract might have seemed unnecessary, if not slavish. Of course, seismic interruptions in the politics of these states (e.g., a loss of sovereignty to a foreign invading power, a social revolution, or a coup) would in some ways create opportunities and challenges that are analogous to those facing new states. Certainly, we do see slower constitution adoption rates in Europe than in the new states in Latin America, but the differences are not enormous; the early 19th century was a period of constitutionalization for any independent state, Latin American or European.

\section{Sources of External Inspiration}

But which constitutional models would attract European drafters? The U.S. model, which understandably shaped much of Latin American constitutional thought, was certainly one plausible option. But Europe was further from the United States and, undoubtedly, used to sending its ideas to the Americas, not the reverse. A reasonable and widely held diffusion assumption is that the spread of practices across hierarchical "classes" of countries (whether operationalized in terms of resources, status, or experience) operates in a top-down direction, but not bottom-up. More generally, the transmission of policies across vertical as opposed to horizontal networks is a common theme in the 
diffusion literature, and some scholars have sought to assess the strength of vertical as opposed to horizontal processes (e.g., D. Collier \& Messick, 1975). Regardless of the strength of these influences, a basic assumption is that those jurisdictions at the top are not particularly influenced by the experiences of those lower down the hierarchy. Thus, the position of European states of the 19th century - many of which were then endowed with not only a long political tradition but also a sizable share of resources and international status - left these states with a more limited set of relevant models. Their elevated position in the international network suggests that, to the extent they are subject to network influences, they would be attuned mostly to the experience of their peers in the region.

Thus, European constitutions in the early 19th century should not be expected to be recycle or even adapt the U.S. document. Among the European set, however, no single model recommended itself as a replacement, at least at the turn of the century. France, the European birthplace of constitutionalism, would seem, in some ways, to have been a logical source of constitutional inspiration, and indeed it was. However, the rather tumultuous constitutional beginning in France-with four constitutions in the first decade of the revolution - did not present an obvious French alternative. Or, more precisely, France presented four alternatives, each of which was inspirational in its own way (albeit not always voluntarily so in the case of its third and fourth constitutions, which Napoleon bestowed on his conquered fiefdoms).

Indeed, a brief accounting of the events and content of this series of French constitutions does much to capture, if not explain, some of the diversity in future European constitutions. The 1791 constitution is, of course, the French charter most celebrated. It was the first and, as such, cleared much of the brush of the ancien régime. It cleared the brush only partly, of course, as the 1791 document left the monarchy intact, although limited. Still, the document legalized the revolution and broke new intellectual ground by formally incorporating the Declaration of Rights, some of which (such as the right to education and other aspects of égalité) went beyond the civil and political rights that were added in that same year to the U.S. Constitution. Not only that, but as an arrangement that accommodated a limited monarchy, the 1791 document would be attractive to future European states with a monarchical presence of their own. Nevertheless, the French revolution would progress, as we know, in an increasingly violent manner and the 1791 document was in effect for only a year. In 1793, it was replaced by a Jacobin-drafted document that removed the king and moved the country further toward a republic. The 1793 constitutiona document a quarter the size of the other three early French constitutions of the decade - would never go into effect. This despite a remarkable outcome in what may have been the first ever popular referendum on a modern 
constitution, in which the public approved the document by a margin of 1.8 million to 11,000 . (One wonders at the brave $1 \%$ that voted against the Reign of Terror.) In any event, constitutional limits did not suit the Terror very well, and the Jacobins dealt with crisis by ruling by decree, not with their constitution. As for the future effect of the 1793 document, Hawgood's (1939) description is apt: "Alone, the Jacobin constitution of 1793 had to wait over half a century before providing acknowledged inspiration, and then it was in France herself [the 1848 constitution]. The world was too busy trying to forget the Jacobins and all their work" (p. 43). Nonetheless, the 1793 document and its republican ideals would ultimately have their intellectual heirs, albeit by skipping a generation or two. The 1795 constitution, which was enacted more to dispel the Terror than to further revolutionary ideals, would have a much more immediate impact on the rest of Europe. That constitution may have backtracked on some democratic principles-Plato, as the constitutional debates noted, would not have held political rights in the new order (Hawgood, 1939)but it was clearly a solidly republican document. Gone was the monarchy, but in other ways the 1795 text was similar to the 1791 text. One significant difference between the two was the addition in 1795 of a second chamber and the inclusion of duties as well as rights, a feature that is most noticeable when one compares future European constitutions with an eye toward identifying their French roots. By 1795, France had taken a more imperial stance toward its neighbors, and French satellites passed over the earlier two French constitutional models and adopted the latest French product. Again, the colorful Hawgood (1939), "The Paris fashion when the countries on her borders began, either under her direct domination or under her spell, to remodel their institutions on French lines, was not the democratic constitution of 1793, but the compromise constitution of 1795 " (p. 40). Nevertheless, the 1795 document would itself become outmoded with Napoleon's coup d'état in November 1799 and the rapid drafting of a new document a month later. Fifteen years of Napoleonic rule abroad meant that the 1799 constitution found itself replicated elsewhere. In Spain, for example, Napoleon's brother Joseph assumed the throne in 1808, accompanied by a new constitution modeled after the French one of 1799.

Spain, indeed, demonstrates quite well the diversity in European constitutions attributable to the various French sources. In 1812, following the short and unhappy life of the Napolean-influenced 1808 constitution, the Spanish Cortes drafted a much admired document that drew on the French text of 1791 and offered a useful update to the first French text for other states emerging from a Bonapartist intervention or interested in a constitutional monarchy. As I describe below, the Portuguese text of 1822 and the very important (and also allegedly widely imitated) Belgian constitution of 1831 were direct descendants of the Spanish constitution of 1812. We can thus 
trace the inheritance of various European constitutional traditions to different sources just within France, a diverse genetic pool that would seem to predict a fair amount of heterogeneity in early European constitutions.

By contrast, the upstart Latin American states found themselves not only without a significant institutional history of their own but also with a more obvious set of models. First, the innovations of the U.S. founders (as fellow young states) are likely to have been more influential in Latin America than they would be across the Atlantic. Any connection between the United States and Latin American states because of geography and generation, of course, was only intensified by their shared experience in emerging from underneath a colonial power. It seems likely that the burgeoning Latin American states were influenced by the constitutional models from Europe as well, if a more limited set of them. Indeed, it is important to bear in mind that despite what seem, in retrospect, like obvious reasons for U.S.-Latin America confluence (because of geography and shared revolutionary experience), the transmission of ideas, goods, and visitors within the Americas paled in comparison to the transmission of these things between the Americas and Europe. Add to that the elevated status of the European states and a more familiar language and culture, and the allure of European constitutions would seem at least equal to that of the United States. Given the timing of the emergence of Latin American states, the Spanish constitution of 1812 made for an obvious model, and one whose language and institutional legacy led to relatively painless adaptation.

\section{Macro Analysis of Constitutional Similarity Patterns}

We can explore these expectations and describe the temporal and spatial differences with data from the Comparative Constitutions Project on the content of constitutions since 1789. The basic approach is to construct a measure of the similarity in content between any two constitutions at their birth. Several considerations arise in building such a measure. The first involves the ingredients of the measure. Our data record almost 600 characteristics of constitutions, and so we are faced with the delicate task of selecting the attributes with which to construct the measure. Furthermore, although we can compare whether two constitutions make the same choices on any given list of provisions, we can also compare more simply whether two constitutions address the same issues. Both alternatives have their advantages, and in this analysis we consider one of each type.

The first measure, call it a measure of inventory similarity (IS), considers the array of topics included in any two constitutions. Such a measure is composed of a series of binary variables indicating whether topic $\mathrm{x}$ or $\mathrm{y}$ is covered 
in the constitution (e.g., Does the constitution specify the method of selection for the head of government, mention a central bank, address the accession of new territory, etc.?). I have identified 70 topics along which I calculate such a measure. I exclude from this list many subtopic items that should be understood as making rather refined distinctions between constitutions. The goal is to identify topics at a general level and thus measure broad areas of inclusion or exclusion in constitutions. I exclude topics that are either highly prevalent or highly rare (appearing in more than $95 \%$ or less than $5 \%$ of all constitutions, respectively) because items with low variance will dilute the power of other items to differentiate constitutional inventories.

The second measure digs more deeply and considers choices within these topics and focuses, in particular, on provisions with respect to rights. One could build a more expansive measure of content similarity that includes items having to do with a wider range of institutional choices. However, a measure of the similarity of institutional choice depends on the assumption that the basic institutional structure is similar-or at least comparable - across constitutions. Such a measure also depends on the comparability of what is included in constitutions - that is, IS. So, for example, it would be challenging to compare the choice of electoral system for the legislature because not all constitutions include a legislature and, of those that do, only a small minority of those specify the selection method in any detail (add to this the further issue of comparing unicameral to bicameral legislatures). By contrast, rights are universal in European and Latin American constitutions and represent a fairly discrete and structure-free set of binary choices along which to make comparisons of content. Each European constitution in our sample provides for at least some rights; the question is which ones. Between 1789 and 1946, drafters in Europe saw fit to provide for 61 of the 73 rights that we include in the survey (after 1946, European drafters would go on to include the other 12).

We can aggregate these two sets of items into indices that allow us to summarize the similarity of any two constitutions across each respective set. Consider first the inventory items. I calculate a measure of IS by summing the number of topics for which any two constitutions agree (i.e., that they both omit or include the topic) and dividing this sum by the number of topics in the set (70). Accordingly, two cases score a 0 if they do not match on a single topic and a 1 if they match on every topic. I calculate this measure of similarity for a sample of 186 of the 366 constitutions written before 1946 and each of their peers. The result is an asymmetric matrix with some 17,000 unique constitutional dyads (one score for each of the 186 constitutions and each of its pairs). The scores across these dyads have a mean of .65 ( $S D=.10)$ and range from .27 to .98 . Not surprisingly, the most similar pairs typically 
involve constitutions from the same country. This is especially true with some of the more prolific constitution producers from Latin America, such as Venezuela and the Dominican Republic, some of whose pairs of constitutions exhibit similarity scores as high as .98 . Within Europe, some of this serial similarity is evident (Spain's 1837 and 1845 constitutions have a score of $.93)$. The highest similarity within Europe for cross-country dyads is .85 for the dyad of Spain (1812) and Portugal (1822), and the lowest is .37 for that of Spain (1808) and Austria (1920). The calculation of the index of rights similarity is comparable. As it turns out, the patterns I describe here are largely similar across the two measures; I focus the discussion that follows on the inventory measure for simplicity.

The sample in question is fairly heterogeneous, and a multivariate analysis of these dyads allows us to test some of the similarity hypotheses more precisely. Table 1 reports the results of an ordinary least squares regression on the IS measure for two models, with the similarity measure rescaled to range from 0 to 100 , instead of 0 to 1 . The first model includes a dummy variable that equals 1 if dyads include constitutions from the same region, and zero otherwise. We might think of this variable as the undifferentiated spatial lag that diffusion researchers often employ. That is, it tests for regional clustering, averaged over the various regions, and, thus, assumes the same amount of within-region similarity across regions. With respect to constitutions written prior to 1946, the caseload is restricted to Western Europe and Latin America, although another 30\% come from the remaining regions. The first model specification also includes two basic controls. Given the serial nature of constitution-making within countries as well as the distinct possibility of generation effects, we control for dyads of constitutions from the same country and the absolute value of the difference in the years in which two constitutions were promulgated, respectively.

The results of that first model suggest that constitutions from the same country are more similar by 7.19 points, an effect almost eerily identical to that of dyads from the same region $(b=7.19)$. That is, constitutions from the same region are, on average, as similar to one another as are constitutions from the same country. The era variable has predictable effects, at least in their direction: Constitutions separated by 100 years are about 4 points less similar on average. The magnitude of this effect is interesting as region appears to be somewhat more influential than era. Countries that are separated by 50 years differ by only 2 points or so, whereas those from the same region are a full 7 points more similar. Regardless, these effects make for useful benchmarks by which to understand the effects we discuss momentarily. The omnibus same-region variable showed a strong effect, but it 
Table I. Predicting Similarity in Constitutional Inventory (Ordinary Least Squares Estimates)

\begin{tabular}{lrrrr}
\hline & \multicolumn{2}{c}{ Model I } & \multicolumn{2}{c}{ Model 2 } \\
\hline Same country dyad & 7.19 & $(0.42)$ & 7.08 & $(0.40)$ \\
Difference in years/100 & -3.81 & $(0.17)$ & -3.85 & $(0.17)$ \\
Same region dyad & 7.18 & $(0.14)$ & 1.51 & $(0.50)$ \\
Latin American dyad & & & 7.28 & $(0.51)$ \\
European dyad & & & -3.77 & $(0.59)$ \\
U.S.-Latin American dyad & & & -1.00 & $(0.84)$ \\
U.S.-European dyad & & & -4.94 & $(1.35)$ \\
Constant & 67.25 & $(0.13)$ & 67.30 & $(0.12)$ \\
$R^{2}$ & .19 & & .25 &
\end{tabular}

Note: $N=17,020$ constitutional dyads from 187 constitutions. Universe is constitutions promulgated prior to 1946. Standard errors are in parentheses.

could be, as we hypothesize, that these effects vary by region, thus yielding an attenuated aggregate effect. To dig more deeply, the second specification includes dummy variables for each of the Latin American and European dyads, respectively, as well as dummy variables for U.S.-Latin American dyads and U.S.-European dyads, thus facilitating tests of our basic expectations. We find that Latin American dyads are considerably more similar than others $(b=7.28)$, an effect nearly equivalent to a move of a full standard deviation on the dependent variable. On the other hand, European dyads are actually less similar to one another than is the average dyad $(b=$ -3.77) and, thus, clearly less similar to one another than are the Latin American dyads. Clearly, the European context in the 19th and early 20th centuries was less conducive to intraregional diffusion than was the Latin American one. If we turn to the second hypothesis, we note that the U.S. Constitution is, if anything, less similar to Latin American constitutions than is the average dyad ( $b=-1.00$, not significantly different from 0$)$. The U.S. Constitution is even less similar, on average, to European constitutions $(b=-4.94)$, as we predicted. Together, these findings suggest that some of our basic assumptions about the adoption of midlife constitutions in Europe may be valid.

\section{Untangling Influences on European Constitutional Design}

We have a general sense, then, that European constitutions exhibited more heterogeneity in their design than did their counterparts in Latin America and 
that the U.S. document was less influential in Europe and even less influential in Latin America than we had thought. It is one thing to show that Europe did not converge on a distinct constitutional form in the same way that Latin American states had. This finding is but the beginning of the story, for a regionwide measure of similarity across eras can obscure spatial and temporal clusters of shared design within the region. Indeed, the varied set of relationships among countries that, as we described, characterized Europe at the turn of the 19th century, to say nothing of subsequent years, may have produced more nuanced patterns of clustering. We explore such patterns in more depth here. In particular, we analyze the centrality of specific constitutional models in 19th-century Europe. Consider, first, the constitutional models available to designers prior to 1820 . By that year, 48 constitutions had been written (17 of which are in our sample). We can assess the centrality of these constitutions by calculating their mean similarity to constitutions that would appear up through 1945. In terms of their similarity in inventory to future documents, the most important of these early constitutions were those of France (1791), Spain (1812, the "Cadíz" constitution), and the documents of the German states of Bavaria (both that of 1808 and that of 1812) and Baden (1818). All of these constitutions exhibit mean similarity scores with future European documents that are at least one standard deviation above the sample mean. That is, they are clearly central and, presumably, at least some of them served as important sources of inspiration. By contrast, the U.S. Constitution as well as that of Sweden (1809) and the French constitutions of 1793, 1795, and 1799 appear fairly peripheral to those that would come later in Europe. If we expand the sample of constitutions to those that were available to drafters during the critical revolutions of 1848 , we note another central document - the Belgian constitution of 1831. Together with the French constitution of 1791 and the Spanish document of 1812, the Belgian constitution of 1831 is among the most central constitutions produced prior to 1848 .

The centrality of these three constitutions makes sense because they are sometimes regarded by historians as landmark documents, if not models for future drafters (e.g., Blaustein \& Sigler, 1988). The French constitution of 1791, of course, represents the first modern constitution on European soil along with the still-born Polish constitution of the same year. ${ }^{5}$ Given its pathbreaking quality, we might not be surprised at its centrality. On the other hand, the constitution lasted only a short time, to be replaced by successive constitutions in 1793, 1795, 1799, and so on-thus sowing the seeds for ridicule in Anglo quarters about Franco hyper-constitutionalism and even friendly fire from within France about whether Gallic territory should be characterized as a garden or graveyard for constitutions. ${ }^{6}$ Indeed, the data confirm that the 
1795 and 1799 documents represent significant departures from the 1791 model. The drafters of the French constitution of 1848 (that of the second republic) drew heavily from the 1791 document, as did other European drafters. In fact, of all the constitutions in Europe written after 1791, the closest and furthest documents to the French constitution of 1848 are both from France: the 1791 document (IS $=.81$ ) and the 1799 document (IS $=.50$ ), respectively. Rarely do we witness such wild swings in content within the same country.

The celebrated Cadíz constitution (Spain 1812) appears to have had a fair amount of original content. Indeed, of the early constitutions, it has the least amount of content in common with prior constitutions. The French constitution of 1791 appears to have been its closest model, but their similarity is only slightly greater than the average for any two constitutions in the sample. We can thus think of it as having drawn from the French document while introducing a significant amount of original material. In turn, the Cadíz constitution appears to have been a model for others in Europe, thus spreading the French ideas as well as its own. Thus, in some ways the Cadíz constitution was uniquely positioned to influence the direction of other states emerging from a Napoleonic order or otherwise shifting toward a republican form of governance. The Cadíz constitution had its most direct impact on the Portuguese constitution of 1822 . The two constitutions are among the most similar of any of the European pairs written prior to 1946 (IS $=.85$ ). Only a glance at the two documents is enough to reveal the striking similarity, but more on that shortly.

The Belgian constitution of 1831 - a famously influential documentappears to have been directly influenced by the Cadíz constitution (IS $=.79$ ). In turn, the Belgian constitution was clearly the model for the ten constitutions of 1848 . Of the 1848 revolutionary documents, the Belgian document and the Bavarian text of 1818 appear to have been the most central, if not influential. In particular, the Italian document of 1848 bears a striking similarity to the Belgian model (IS $=.77$ ).

And what of the United States in Europe? Was the product of the U.S. founders as peripheral as the average effects would lead us to believe? We know that various European constitutional assemblies had copies at hand of the U.S. Constitution, as well as the Declaration of Independence, the state constitutions, and even the Federalist Papers (Billias, 1990). Strangely, the only European constitution whose similarity to the U.S. document is more than one standard deviation above the sample average is Norway 1814 (IS = .73), although the U.S. resemblance to others (e.g., France 1791 and Austria 1919 ) is clearly above average. It appears likely that some of the U.S. impact on constitutional design, a modest as it was, may have operated indirectly through the document's impact on the French text of 1791. 


\section{Episodes of Democratic Reform: Spain and Portugal}

We now turn our attention to the Iberian peninsula in the early nineteenth century. The macro evidence above seems to more than corroborate the oftencited supposition that the Spanish constitution of 1812 strongly influenced constitutional drafters elsewhere, among them, drafters in Portugal in $1822 .{ }^{7}$ For various reasons, it makes sense to look more closely at the process of institutional design in these two episodes. Most importantly, as I describe below, the cases were similar in many ways except for one - a factor that, but for diffusion, should have resulted in two very different constitutional texts. For us, then, two counterfactual queries are relevant: (a) How might the Portuguese constitution of 1822 have been different had its drafters not consulted the Spanish document? and relatedly (b) How might the course of democratic reform in Portugal in subsequent generations been different if the Portuguese had adopted a more indigenous document? These are, undoubtedly, probing questions and I do not propose to offer the definitive historiography of Iberian liberalism in the space of several pages. On the other hand, taking a hard run at these important questions helps to illustrate the democratic stakes for constitutional drafters and, in turn, the consequences of constitutional diffusion.

In many ways, the historical context leading to the drafting of the Spanish and Portuguese charters was quite similar. After the French revolution, both monarchies tried to temper similar liberal movements at home, notably by sealing off communication with France. Later, as France entered its imperial phase, neither was able to resist Napoleon's grande armée successfully enough, and by 1808 Napoleon's brother Joseph sat on the throne in Spain. In both countries, the monarchy had fled. Spain's Carlos IV had left for France, where he would be joined by his son Fernando VII, who would become the vessel in which Spanish monarchists poured their executive hopes (he would be known as el deseado, the "desired," during this time). Meanwhile, in Portugal Dom João had left for Rio de Janeiro, thus transferring the seat of the erstwhile Portuguese empire to Brazil (interestingly, Spain's Carlos had resisted suggestions by his advisors to make the same move to the country's American outposts). In Spain, Bonaparte had managed to impose the "first" Spanish constitution in 1808. However, the first autochthonous constitutional effort in Spain occurred in 1812, while still under siege by the French; the Portuguese moment came 10 years later in 1822 . Both Iberian countries would have similar constitutional concerns that were, incidentally, not too different from those of revolutionary France: how to manage the church, which still held inquisitions in each country to the 
dismay of liberals; how to accommodate their anxious colonial residents; and whether or not to discontinue a system of seigniorage. Not to mention, of course, the issue of what role the monarchy would play.

The setting and membership of the constitutional drafting assemblies in Spain and Portugal were strikingly different. During the French occupation (or, rather, the peninsular war as it became known in England), Spanish local authorities carried out a decentralized guerrilla war, whereas the national authorities maintained a shadow government of sorts. By 1810, that junta had managed to assemble a version of the Cortes (the name for the representative assembly in both Spain and Portugal) in Cadíz, a unique city and port in southwestern Spain. As a refuge from Bonaparte, Cadíz was ideal- the city sits on a narrow strip of land just off the coast and, as home to what was left of the Spanish navy, was easily defended. Culturally, Cadíz was exceptional as well. After sand bars rendered the Guadalquivir River impassable in the 1700s and thus any real shipping in and out of Sevilla, almost all of the Americas trade went through Cadíz, giving the city a decidedly cosmopolitan and mercantile feel. As one of the most liberal cities in Spain, Cadíz made for a rather unrepresentative host to a constitutional convention in $1812 .{ }^{8}$ Moreover, the members of the Cortes who assembled in Cadíz were themselves atypical. Although the members of the Cortes were to be elected (indirectly) throughout war-torn Spain, elections were suspended in areas held tightly by the French, which not coincidentally, were the most conservative areas. These seats were filled with substitute members selected from the ranks of liberal authorities in Cadíz by the already disproportionately liberal Cortes. All this amounted to a highly unrepresentative Cortes, tailor made to produce an atypically liberal document. As Stanley Payne (1973) puts it, "Conservatives were outnumbered, outmaneuvered, and outtalked at Cádiz" (p. 427).

Compare this group with the Cortes that assembled in Lisbon in 1820. Lisbon was not quite the liberal haven that Cadíz had been, and the election of deputies appears to have resulted in a group that had, if anything, a conservative bent. Piteira Santos's (1962) narrative of the era suggests a group that grossly overrepresented rural elites and landholders. ${ }^{9}$ There is also, fortunately, some scattered but reasonably comparable data on the profile of each of the Cortes, and it is possible to make some rough comparisons (Table 2). In terms of economic interests, the differences do not appear as stark as the various narratives suggest, but of course professional designations of the members may be misleading. The strong presence of government officials (presumably mostly local Cadíz authorities serving as substitutes) is quite noticeable in the Cadíz Cortes. But whatever liberal atmosphere pervaded at Cadíz, it is clear that the church was better represented there (where they 
Table 2. Membership in Drafting Assemblies, by Profession, Spanish Cortes (1810), Portuguese Cortes (I82I)

\begin{tabular}{|c|c|c|c|c|}
\hline \multirow[b]{2}{*}{ Group } & \multicolumn{2}{|c|}{ Spain } & \multicolumn{2}{|c|}{ Portugal } \\
\hline & $n$ & $\%$ & $n$ & $\%$ \\
\hline Lawyers and judges ${ }^{a}$ & 60 & 20 & 39 & 39 \\
\hline Intellectuals $\mathrm{s}^{\mathrm{b}}$ & 20 & 7 & 21 & 21 \\
\hline Clergy & 97 & 32 & 16 & 16 \\
\hline Military & 46 & 15 & 10 & 10 \\
\hline Physicians & & & 6 & 6 \\
\hline Landowners & 15 & 5 & 5 & 5 \\
\hline Merchants & & & 3 & 3 \\
\hline Government employees & 55 & 18 & & \\
\hline Miscellaneous & 10 & 3 & & \\
\hline Total membership & 303 & 100 & 100 & 100 \\
\hline
\end{tabular}

Sources: Fernández Almagro (1928, p. 82), Farias (1975), and Piteira Santos (1962).

a. Labeled as "lawyers" by Fernández Almagro and as "magistrates and jurists" by Piteira Santos. I combine the groups.

b. Labeled as "intellectuals" by Fernández Almagro and as "teachers and liberal professionals" by Piteira Santos. I combine the two groups.

were one third of the membership) than they were in Lisbon (where they accounted for one sixth). Moreover, the clergy appears to have been even better represented in the all-important drafting committee in Cadíz, with 6 of 13 spots (Suarez, 1976, p. 21). At the risk of overdrawing differences, what emerges, then, is a picture of two strikingly different settings with two decidedly different casts and, presumably, two different predispositions toward constitutional design.

Nevertheless, the two assemblies produced very similar charters, with the Portuguese text notably drawn from the Spanish. There are obvious stylistic similarities: The charters have the structure, each with roughly 10 chapters on the same topics, within which they provide for a very similar governmental structure and a very similar set of relationships between the king and the Cortes. The one obvious stylistic difference is that the Portuguese charter of 1822 leads with a section on rights, whereas the Spanish constitution integrates these rights that are almost identical throughout the body of the text. The language itself is almost identical in most articles, given the similarity of the syntax and shared cognates between Portuguese and Spanish. Indeed, unless one were well acquainted with either document, it is likely that one could pass for the other. To take a small but discrete example, consider the 
provisions from Article 117 (Portugal 1822) and Article 159 (Spain 1812), both of which establish a permanent committee of the Cortes, composed of seven members, three from the overseas provinces (the Americas, mostly), three from the peninsula, and one to be chosen by lot between a peninsular and overseas deputy. True, both Spain and Portugal were at the time attempting to hold on to their colonial possessions in the Americas, but it seems likely that the two sets of drafters would have elected a different balance between peninsular and overseas representation in this important committee. Another striking example comes at the conclusion of the charters, both of which close with a self-contained chapter on education, including identical provisions for the establishment of primary schools and universities throughout the country to teach Catholic catechism and civic lessons as well as a provision for academic freedom. This sort of broad attention to education is not the typical material of constitutions - at least those created in Philadelphia or Paris.

None of this is not to say that the Portuguese drafters adopted the Spanish document uncritically, or without revision. For example, the Portuguese opted importantly for an elected Cortes, whereas the Spanish charter envisioned a rather tortured three-stage set of indirect elections. Also, the Spanish constitution required that members of the Cortes sit out a term before their reelection; the Portuguese constitution stated explicitly that Cortes members could be reelected. One also notices small, but symbolically important flourishes: The phrase "the person of the King is inviolable" leads the section on the king in the Cadíz constitution but is left to the end of the same section in the Portuguese charter. Remarkably, it is possible that some of these differences came at the encouragement of Jeremy Bentham. Bentham had been looking for an outlet for his political philosophy for some time and, at the age of 72, he appears to have seen the Portuguese constitutional process as his last best hope. He corresponded relentlessly with at least three members of the Cortes, to whom he also sent 20 of his works, some of which were introduced into the official record of the Cortes and ordered to be translated. In a "Letter to the Portuguese Nation" that he published in a London magazine, he recommended that the Portuguese adopt a version of the Spanish constitution with some explicit modifications, two of which were the implementation of direct elections and the removal of legislative term limits (Carvalho dos Santos, 1982; Fuller, 2000). The extent of his influence is unclear, but it does appear that the Portuguese delegates operated in concert with his advice (whether independently or not). Bentham's call for the end of Iberian colonialism - an essay playfully entitled "Rid Yourselves of Ultramaria!" - certainly did not register. So, apart from a few notable exceptions, it is clear that the Spanish charter had a strong influence on members of the Portuguese Cortes. 
Let us consider some of the more consequential decisions in Cadíz and, thereby, Lisbon. A significant issue in the Cadíz assembly had to do with the role of the church. The resulting document did away with courts of inquisition, which was clearly opposed by Cadíz liberals, but in other respects the representatives of the clergy were able to stamp the constitution with a clearly ecclesiastical identity, something decidedly foreign to the tradition of France 1791. A chapter on Religion begins and ends with Article 12 that declares the "religion of the Spanish nation is, and shall be perpetually, Apostolic Roman Catholic, the only true religion. The nation protects it by wise and just laws and prohibits the exercise of any other whatsoever." The charter spells out oaths of office that begin with the duty to protect the church, provisions to teach religious material in schools, and so on. Each of these provisions is carried through identically in the Portuguese document. It is unclear whether and how the Portuguese would have provided for the church (e.g., regarding courts of inquisition, which existed in Portugal to that time as well) had they not followed the Spanish example in lockstep. The predisposition of Portuguese delegates was decidedly mixed: Compared to the Spanish Cortes, the Portuguese body was arguably more conservative, but yet the role of the clergy was decidedly a smaller one (at least numerically). So, one may have expected an arrangement closer to the French model. One thing that is clear is that because the Spanish provisions were imported wholesale, we can never know the Portuguese independent preference.

Perhaps the most consequential bit of inheritance from the Spanish document had to do with the amendment rules. The Spanish document insists on a remarkably firm commitment by restricting any amendments for a period of eight years after the charter has been put in force (after which amendments were approved by a two thirds vote by consecutive legislatures). The Portuguese constitution struck a slightly more flexible stance, insisting on a four-year waiting period and then passage by two thirds in consecutive assemblies. A handful of subsequent constitutions have similarly entrenched themselves with waiting periods, most following the example of the Spanish charter, and to a constitution they have met a rather disastrous fate. The Spanish and Portuguese constitutions - as important as they were historically - would be no exceptions. Each would be replaced in a matter of years, to be reinstated later in various forms throughout the century, but replaced they were. Admittedly, these were tumultuous years in both countries, but amendment intransigence did not help the documents adapt. Stepping outside of Iberia, I should note a striking (perhaps the most striking) empirical regularity with respect to the lifespan of constitutional systems: Those documents that are overly costly to reform (read: hard to amend) exhibit a significantly higher risk of death (Elkins et al., 2009). In this sense, the Spanish constitution and its Portuguese 
offspring are all too typical. The subsequent Portuguese constitution of 1826 , which would be in place until 1910, opted for a much more flexible amendment procedure (amendments are passed like ordinary legislation by successive legislatures). In 1885, legislators availed themselves of the flexible procedure to revise the amendment procedure itself and reverted to the 1822 rule - a four-year waiting period between two amendment proposals. Not purely coincidentally, 25 years later these rules would be evaded and the constitution would be replaced entirely.

It is hard to say how the decisions taken in 1822 affected the development of politics in Portugal in subsequent years. It is clear that many of the 1822 ideas took shape in the 1826 constitution and continued in its various iterations up through the transition to a full republic in 1910. The making of the 1826 constitution is itself an interesting story, which I leave to another time, but suffice it to say that it is an indirect descendant of the 1812 Spanish constitution via the Brazilian independence constitution of 1824, which descended from the Portuguese constitution of 1822. Even the republican structure of the 1910 document owed something to the original Portuguese constitution of 1822: For example, republican Portugal maintained a unicameral legislature, the constitution included a similar slate of rights as did the 1822 document, and so on. In short, the adoption of the Spanish model had a decided impact on the stability of the 1822 Portuguese text and, certainly, on the character of institutions for years to come.

\section{Conclusion}

This article argues in behalf of the strong assumption - perhaps controversial in some circles - that the content of national constitutions affects both the quality of democracy and the expected frequency of democratic reform. If one accepts this assumption, the implication is that theories of constitutional design should be central to the work of those interested in tracing the roots of democracy. In turn, any theory of constitutional design must begin with the overwhelming prima facie evidence of the diffusion - by some mechanism or another - of constitutional ideas from one context to another. So to understand the shaping of national constitutions in a given country, one must take into account the constitutional experiences and models of those countries that inspire its drafters. However, scholars have so far lacked some basic empirical knowledge concerning the external influences on constitutional design in 19th-century Europe. Which constitutions were most influential? How can we characterize the networks of influence across countries? We set out some basic hypotheses along these lines and then test them with an original set of data on the content of constitutions. Some interesting patterns emerge. 
Among them, we note that the Western European story is decidedly not one of regional convergence. It is rather the opposite. The average pair of early European constitutions is less alike than is the average pair of constitutions, whether from the same region or not. When we dig more deeply into the pattern of constitutional reform, a number of explanations emerge. Not only is it probably the case that distinct European national traditions and legacies led to regional diversity, but it is also the case that the lack of a single successful model in the early years of constitutionalization led to increased experimentation and the development subregional clusters of constitutionalism. The constitutionalization of Western Europe is still very much a story of diffusion. However, the region exhibits a more complicated set of inheritances with multiple blood lines. In some sense then, evidence of diffusion in Europe - a region where such processes were not expected to have a particularly strong historical impact-makes the case for diffusion explanations more generally. In any event, it seems clear that suspicions of widespread contagion of constitutional form cannot be rejected, and even further investigation of these patterns seems warranted. These conclusions serve to disturb some of the rather settled notions of European democratization, which tend to emphasize variation in domestic class structure and other important factors inside of nation-states. At the very least, it seems reasonable at this point to revisit, perhaps more skeptically, some of the oft-repeated story lines from the first wave of democratization.

\section{Acknowledgments}

I thank Giovanni Capoccia and Daniel Ziblatt for encouraging me to write this article and for steering me away from some blind alleys. They, along with Wolfgang Merkel, Tim Buthe, and Kurt Weyland, provided excellent comments on various drafts. Manuel Balan provided expert research assistance. I also owe a debt of gratitude to my collaborators on the Comparative Constitutions Project, Tom Ginsburg and James Melton, who helped produce much of the data employed in the analysis herein.

\section{Declaration of Conflicting Interests}

The author declared no potential conflicts of interests with respect to the authorship and/or publication of this article.

\section{Financial Disclosure/Funding}

The author received no financial support for the research and/or authorship of this article. 


\section{Notes}

1. Nonconstitutionalist has come to refer to the idea of restraining political actors, which though certainly a central purpose of constitutions, is not one and the same as the label would suggest.

2. Regime change here is measured by a three-unit move one way or another on the Polity 0-20 scale, and change in regime and constitution is scored as coincident if they occur within 1 year of each other.

3. Thomas Jefferson to John Adams, August 30, 1787 (in Cappon, 1959, p. 196).

4. Online at comparativeconstitutionsproject.org.

5. The Polish document was never put into force.

6. I am thinking, for example, about the old yarn about the man who goes to the library in search of the French constitution only to be told that the library does not stock periodicals.

7. Jordi Solé Tura and Eliseo Aja (1977) cite the early-20th-century scholar MirkineGuetzevich as crediting the Spanish constitution of 1812 with being even more influential than the U.S. Constitution and the French constitution of 1791.

8. As Payne (1973) describes Cadíz and its product,

The liberal Cortes and its resulting constitution could probably have taken the shape they did only in Cádiz, the most liberal city in the peninsula at that time. Open to foreign influence, living off the American trade, led mostly by a middle class that had made its money from commerce and not landed dominion, the Cádiz environment gave a decisive thrust to constitutional reformism. (p. 425)

9. Payne (1973) describes them thusly,

The characteristic that the deputies had most in common was that the great majority of them represented the rural and landholding upper middle class and were especially interested in advancing the position of that class. The most conservative deputies were those chosen from the Beira region, seat of the country's only university (Coimbra). (pp. 517-518)

\section{References}

Alvarez, M., Cheibub, J. A., Limongi, F., \& Przeworski, A. (1996). Classifying political regimes. Studies in Comparative International Development, 31(2), 3-36.

Billias, G. A. (1990). American constitutionalism abroad: Selected essays in comparative constitutional history. New York, NY: Greenwood. 
Blaustein, A. P., \& Sigler, J. A. (1988). Constitutions that made history. New York, NY: Paragon.

Capoccia, G., \& Kelemen, R. D. (2007). The study of critical junctures: Theory, narrative, and counterfactuals in institutional theory. World Politics, 59, 341-369.

Capoccia, G., \& Ziblatt, D. (2010). The historical turn in democratization studies: A new research agenda for Europe and beyond. Comparative Political Studies, 931-968.

Cappon, L. J. (Ed.). (1959). The Adams-Jefferson Letters (Vol. 1). Chapel Hill: University of North Carolina Press.

Collier, D., \& Messick, R. E. (1975). Functional requisites versus diffusion: Testing alternative explanations of social security adoption. American Political Science Review, 69, 1299-1315.

Collier, R. B (1993). Combining alternative perspectives: Internal trajectories versus external influences as explanations of Latin American politics in the 1940's. Comparative Politics, 26, 1-29.

Coppedge, M., \& Brinks, D. (2006). Diffusion is no illusion: Neighbor emulation in the third wave of democracy. Comparative Political Studies, 39, 463-489.

Duverger, M. (1954). Political parties. London, UK: Methuen.

Elkins, Z. (2009). Constitutional Networks. In Miles Kahler (Ed.), Networked politics: Agency, power, and governance. Ithaca, NY: Cornell University Press.

Elkins, Z., Ginsburg, T., \& Melton, J. (2010). The Comparative Constitutions Project. Available at https://comparativeconstitutionsproject.org

Elkins, Z., Ginsburg, T., \& Melton, J. (2009). The endurance of national constitutions. Cambridge, UK: Cambridge University Press.

Farias, P. (1975). Breve historia constitucional de España $[$ A short constitutional history of Spain]. Madrid, Spain: Doncel.

Fernández Almagro, M. (1928). Orígenes del régimen constitucional en España [Origins of the constitutional regime in Spain]. Barcelona, Spain: Editorial Labor.

Fuller, C. (Ed.). (2000). The correspondence of Jeremy Bentham, Vol. 11. Oxford: Oxford University Press.

Hawgood, J. A. (1939). Modern constitutions since 1787. New York, NY: Van Nostrand Reinhold.

Kopstein, J., \& Reilly, D. (2000). Geographic diffusion and the transformation of the postcommunist world. World Politics, 53, 1-37.

Lindberg, S. I. (2006). Democracy and elections in Africa. Baltimore, MD: Johns Hopkins University Press.

Lipset, S. M., \& Rokkan, S. (1967). Cleavage structures, party systems, and voter alignments. New York, NY: Free Press.

Luebbert, G. (1991). Liberalism, fascism, and social democracy: The origins of political regimes in interwar Europe. Oxford, UK: Oxford University Press. 
Moore, B. (1966). The social origins of democracy and dictatorship: Lords and peasants in the making of the modern world. Boston, MA: Beacon.

Ordeshook, P. (1992). Constitutional stability. Constitutional Political Economy, 3, 137-175.

Payne, S. G. (1973. A history of Spain and Portugal. Madison: University of Wisconsin Press.

Piteira Santos, F. (1962). Geograna e economia da Revoluçao de 1820 [Geograna and economy of the Revolution of 1820]. Lisbon, Portugal: Publicações Europa-América.

Posner, D. N., \& Young, D. J. (2007). The institutionalization of political power in Africa. Journal of Democracy, 18, 126-140.

Przeworski, A. (1991). Democracy and the market. Cambridge, UK: Cambridge University Press.

Przeworski, A. (n.d.). In defense of elections. Unpublished manuscript.

Rueschemeyer, D., Stephens, J., \& Stephens, E. (1992). Capitalist development and democracy. Cambridge, UK: Polity.

Rustow, D. (1970). Transitions to democracy: Toward a dynamic model. Comparative Politics, 2, 337-363.

Santos, M. H. (1982). A maior felicidade do maior número. Bentham e a Constituição Portuguesa de 1822. In O Liberalismo na Península Ibérica, Vol 1. Lisbon: Ed. Sá da Costa.

Solé Tura, J., \& Aja, E. (1977). Constituciones y períodos constituyentes en España (1808-1936) [Constitutions and constituent periods in Spain (1808-1936)]. Madrid, Spain: Siglo XXI.

Suarez, F. (1976). Actas de la Comisión de Constitución, 1811-1813 [Acts of the Constitutional Commission, 1811-1813]. Madrid, Spain: Ediciones del Instituto de Estudios.

Weingast, B. (1997). The political foundations of democracy and the rule of law. American Political Science Review, 91, 245-263.

\section{Bio}

Zachary Elkins is an assistant professor in the Department of Government at the University of Texas at Austin. His research focuses on issues of democracy, institutional reform, research methods, and national identity, with an emphasis on cases in Latin America. He is currently completing a book manuscript, Designed by Diffusion: Constitutional Reform in Developing Democracies, which examines the design and diffusion of democratic institutions, and he is the coauthor of The Endurance of National Constitutions, which explores the factors that led to the survival of national constitutions. With Tom Ginsburg, he codirects both the Comparative Constitutions Project, a National Science Foundation-funded initiative to understand the causes and consequences of constitutional choices, and the Web site constitutionmaking.org, which provides resources and analysis for constitutional drafters in new democracies. 